Jurnal Laut Khatulistiwa, Vol. 4. No. 3 (October, 2021), Hal. 101-108.

ISSN : 2614-6142 (Printed), 2614-8005 (Online)

http://jurnal.untan.ac.id/index.php/lk

JURNAL LAUT

KHATULISTIWA

\title{
Distribusi Horizontal Karang Jamur (Scleractinia: Fungiidae) di Perairan Pulau Kabung Kabupaten Bengkayang, Kalimantan Barat
}

\section{Horizontal Distribution of Mushroom Coral (Scleractinian: Fungiidae) in Kabung Island Bengkayang district, West Kalimantan}

\author{
Muhamad Sulthaanan Saputra ${ }^{1 *}$, Junardi ${ }^{1}$, Firman Saputra ${ }^{1}$ \\ 1Program Studi Biologi, FMIPA Universitas Tanjungpura, Pontianak, Indonesia \\ *E-mail : Sulthaanan123@gmail.com
}

Received : 14 June 2021; Accepted: 20 Oktober 2021

Published: 31 October (C) Author(s) 2021. This article is open access

\begin{abstract}
Mushroom coral (Fungiidae) is found in Indonesian waters as many as 29 species, which one is Kabung island, West Kalimantan. Thereis no data available about the species and distribution of the Mushroom coral in Kabung Island. The aim of this research is to obtain data on the distribution and environmental factors that affect mushroom coral. The research was conducted in July - September 2019 using the method (belt transect). The density of mushroom coral found in the waters of Kabung Island ranged from 0.01 to $0.05 \mathrm{ind} / \mathrm{m}^{2}$, the relative density ranged from $7.62-32.88 \%$, the presence frequency was $66.67-100 \%$. The pattern of mushroom coral's distribution in Kabung Island is included to the grouping category (Cycloseris vaughani, Fungia fungites, Fungia horrida and Fungia spinifer) and random (Fungia scabra). Environmental factors that influence the distribution of mushroom coral in Kabung Island such as brightness, dissolved oxygen, calcium, and alkalinity.
\end{abstract}

Keywords: Distribution, Mushroom Coral, Kabung Island

\begin{abstract}
Abstrak
Karang jamur (Fungiidae) ditemukan di perairan Indonesia sebanyak 29 spesies salah satunya berada di wilayah perairan pulau Kabung, Kalimantan Barat. Hingga saat ini belum tersedia data apapun terkait spesies dan sebaran Karang Jamur yang berada di wilayah perairan Pulau Kabung. Tujuan dari penelitian ini adalah untuk mendapatkan data tentang distribusi dan faktor lingkungan yang mempengaruhi karang jamur. Penelitian dilakukan pada bulan Juli-September 2019 dengan menggunakan metode (transek sabuk). Kepadatan karang jamur yang ditemukan di perairan Pulau Kabung berkisar antara 0,01-0,05 ind $/ \mathrm{m}^{2}$, kepadatan relatif berkisar 7,62-32,88\%, frekuensi kehadiran 66,67-100\%. Pola sebaran karang jamur di perairan Pulau Kabung termasuk dalam kategori mengelompok (Cycloseris vaughani, Fungia fungites, Fungia horrida dan Fungia spinifer) dan acak (Fungia scabra). Faktor lingkungan yang mempengaruhi distribusi karang jamur di perairan Pulau Kabung seperti kecerahan, oksigen terlarut, kalsium, dan alkalinitas.
\end{abstract}

Kata kunci: Distribusi, Karang Jamur, Pulau Kabung

\section{Pendahuluan}

Karang jamur (Fungiidae) merupakan salah satu famili dari karang keras (Scleractinian) yang sebagian genus hidupnya lepas dari substrat (free-living). Famili karang ini ditemukan di perairan Indonesia sebanyak 29 spesies (Suharsono, 2010). Menurut Suharsono (2010), karang Fungiidae memiliki karakteristik yang khas karena hidup soliter atau membentuk koloni, baik secara bebas maupun melekat pada substrat. Famili karang ini juga merupakan karang yang unik diantara jenis scleractinian lainnya karena sebagian besar individu karang ini mampu berpindah dari satu habitat ke habitat lain baik pada fase 
Jurnal Laut Khatulistiwa, Vol. 4. No. 3 (October, 2021), Hal. 101-108.

larva maupun dewasa (Yamashiro dan Yamazato, 1996).

Karang jamur (Fungiidae) memiliki banyak peranan yang penting dalam ekosistem terumbu karang. Salah satu perannya adalah untuk memperluas wilayah terumbu karang. Karang ini dapat memperluas wilayahnya dengan cara berpindah dari lereng terumbu ke substrat yang lunak. Selain itu, karang jamur berperan dalam menyediakan substrat keras sebagai tempat untuk avertebrata berasosiasi (Chadwick dan Loya, 1992). Keberadaan Fungiidae dalam ekosistem terumbu karang juga dapat memberikan informasi tentang keadaan ekosistem tersebut. Jika jenis karang ini melimpah, maka ekosistem tersebut terindikasi mengalami kerusakan (Mampuk et al., 2013).

Menurut Hoeksema et al. (2014), status konservasi beberapa jenis karang jamur (Fungiidae) saat ini masuk dalam kategori hampir terancam (near threatened). Keberadaan karang jamur yang hampir terancam karena adanya degradasi habitat. Faktor-faktor yang mempengaruhi degradasi habitat, seperti kompetisi, perubahan iklim, dan populasi yang tidak stabil (Wilkinson, 2004). Ancaman terjadinya degradasi habitat juga dapat terjadi diperairan Kalimantan Barat termasuk Pulau Kabung.

Pulau Kabung adalah salah satu pulau di Kecamatan Sungai Raya Kepulauan, Kabupaten Bengkayang yang menjadi lokasi ditemukanya karang Fungiidae. Status konservasi di Pulau Kabung masuk dalam kategori konservasi kawasan perairan daerah. Aktivitas didalamnya masih dipergunakan sebagai tempat kegiatan penduduk yang sebagian besar berprofesi sebagai nelayan. Pulau ini juga dijadikan sebagai area pariwisata daerah karena memiliki keindahan alam bawah laut (DKP Kalbar, 2005), Potensi alam bawah laut di Pulau Kabung sampai saat ini belum memiliki data ilmiah terutama tentang kondisi dan populasi karang Fungiidae.

Penelitian tentang karang jamur di Indonesia pernah dilakukan untuk mengamati kondisi habitat oleh Subhan et al. (2011), di perairan Pulau Pramuka, Kepulauan Seribu, kemudian penelitian yang dilakukan oleh Mampuk et al. (2013), di perairan Malalayang Manado, dan Hoeksema (2012), di Kepulauan Spermonde Sulawesi Selatan. Penelitian tentang distribusi karang fungiidae, pernah dilakukan oleh Wahyu (2004), yang menyatakan pola penyebaran Fungia fungites yang cenderung menyebar merata dan pola penyebarannya dipengaruhi oleh kompetisi. Penelitian lain yang dilakukan oleh Mampuk (2013), menyatakan pola penyebaran Fungiidae yang mengelompok. Perbedaan hasil yang di dapatkan dari dua penelitian tersebut dikarenakan pola penyebaran Fungiidae sangat bergantung pada kondisi habitat. Informasi tentang kondisi habitat di pulau kabung sampai saat ini datanya belum tersedia, sehingga masih diperlukan penelitian tentang pola penyebaran Fungiidae di Pulau Kabung

\section{Metode}

\subsection{Lokasi Penelitian}

Penelitian dilakukan pada perairan Pulau Kabung, Kecamatan Sungai Raya Kepulauan, Kabupaten Bengkayang, Kalimantan Barat. Secara geografis Pulau Kabung terletak diantara $0^{\circ}$ 50' 25.88" Lintang Utara dan 108ㅇ 48 ' 43.310" Bujur Timur. Luas wilayah Pulau Kabung berkisar 1.015 Ha. Keberadaan Pulau Kabung masuk dalam Kecamatan Sungai Raya Kepulauan, Kabupaten Bengkayang. Wilayah bagian utara berbatasan langsung dengan Kelurahan Sedau Kecamatan Singkawang Selatan, sebelah timur berbatasan dengan Kecamatan Monterado, sebelah selatan berbatasan dengan Kecamatan Sungai Raya Bengkayang, dan sebelah barat berbatasan langsung dengan Laut Natuna. Stasiun penelitian di tentukan berdasarkan perbedaan rona lingkungan. Berdasarkan hasil survei ditetapkan 3 stasiun pengambilan sampel, pada masing masing stasiun ditetapkan 3 belt transek. Peta lokasi penelitian disajikan pada Gambar 1. 
Jurnal Laut Khatulistiwa, Vol. 4. No. 3 (October, 2021), Hal. 101-108.

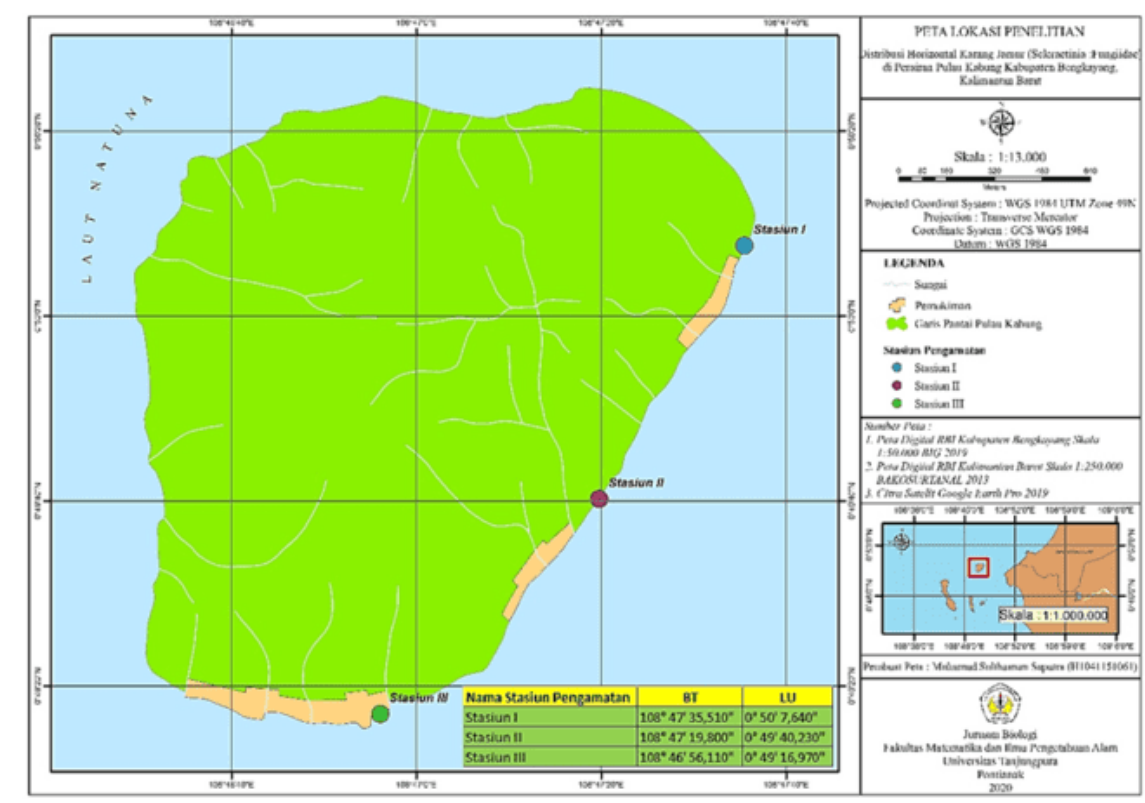

Gambar 1. Peta Lokasi Penelitian di Perairan Pulau Kabung (Map of research location in the waters Kabung Island).

\subsection{Pengambilan Sampel}

Pengambilan sampel pada masingmasing stasiun menggunakan transek sabuk (Belt Transect). Setiap stasiun terdiri dari 3 transek dengan panjang transek $25 \mathrm{~m}$ (English et al., 1997). Penetapan transek dilakukan dari arah bibir pantai dengan jarak $5 \mathrm{~m}$, yang sejajar dengan arah garis pantai (horizontal). Apabila ditemukan karang jamur dilakukan transek dari titik 0-25 $\mathrm{m}$ dengan jarak masing-masing transek $10 \mathrm{~m}$. Pengambilan sampel karang jamur di lakukan pada setiap transek.

Pengamatan dan pengambilan sampel dilakukan di tengah sabuk transek kemudian dilihat dari sebelah sisi kanan dan kiri, pengamatan dibantu dengan gambar karang Fungiidae (Coral Finders), dilakukan pencatatan terhadap karang yang didapatkan dan dihitung banyaknya jumlah masing masing dari jenis karang Fungiidae. Sampel individu yang belum dapat diidentifikasi di lapangan akan dibawa ke laboratorium untuk diidentifikasi lebih lanjut. Individu Fungiidae yang akan dibawa ke laboratorium dipreparasi dengan cara direndam dalam aquades dan

\section{HASIL}

\subsection{Komposisi Spesies Karang Jamur Di Perairan Pulau Kabung}

Karang Jamur (Fungiidae) yang ditemukan di perairan Pulau Kabung dibersihkan dengan ditergen kemudian dikeringkan dibawah sinar matahari. Proses identifikasi akan dilakukan Laboratorium Zoologi FMIPA Untan.

\subsection{Identifikasi Sampel Karang Jamur}

Sampel karang jamur diidentifikasi berdasarkan karakter morfologi meliputi warna permukaan tubuh, warna tentakel, struktur konfigurasi koralit, bentuk koloni, dan struktur septa. Buku acuan yang digunakan untuk identifikasi adalah Veron (2000) dan Suharsono (2008).

\subsection{Pengukuran Parameter Lingkungan}

Pengukuran parameter fisika kimia air dilakukan secara In - situ (secara langsung) di lapangan dan Ex - situ (tidak langsung) di laboratorium kualitas dan kesehatan lahan Fakultas Pertanian Universitas Tanjungpura. Pengukuran parameter lingkungan dilakukan di setiap stasiun pengambilan sampel, parameter yang diukur yaitu alkalinitas, kalsium, kecerahan, kedalaman, salinitas, $\mathrm{pH}$, suhu, oksigen dan karbondioksida terlarut

berjumlah lima spesies, terdiri atas empat genus Fungia berupa Fungia fungites (Gambar 2b), Fungia horrida (Gambar 2c), Fungia scabra (Gambar 1d) dan Fungia spinifer (Gambar 2e ) serta satu genus Cycloseris berupa Cycloseris vaughani (Gambar 2a). Komposisi spesies 
Jurnal Laut Khatulistiwa, Vol. 4. No. 3 (October, 2021), Hal. 101-108.

karang jamur yang ditemukan disajikan pada Tabel 1. Jumlah individu karang jamur yang didapatkan berdasarkan genus Cycloseris dan genus Fungia, pada Stasiun I, II dan III berturut-turut untuk Fungia sebanyak 65 individu, 80 individu dan 54 individu. Jumlah individu genus Cycloseris yang didapatkan pada masing-masing stasiun berturut-turut didapatkan sebanyak 26 individu, 38 individu dan 19 individu.
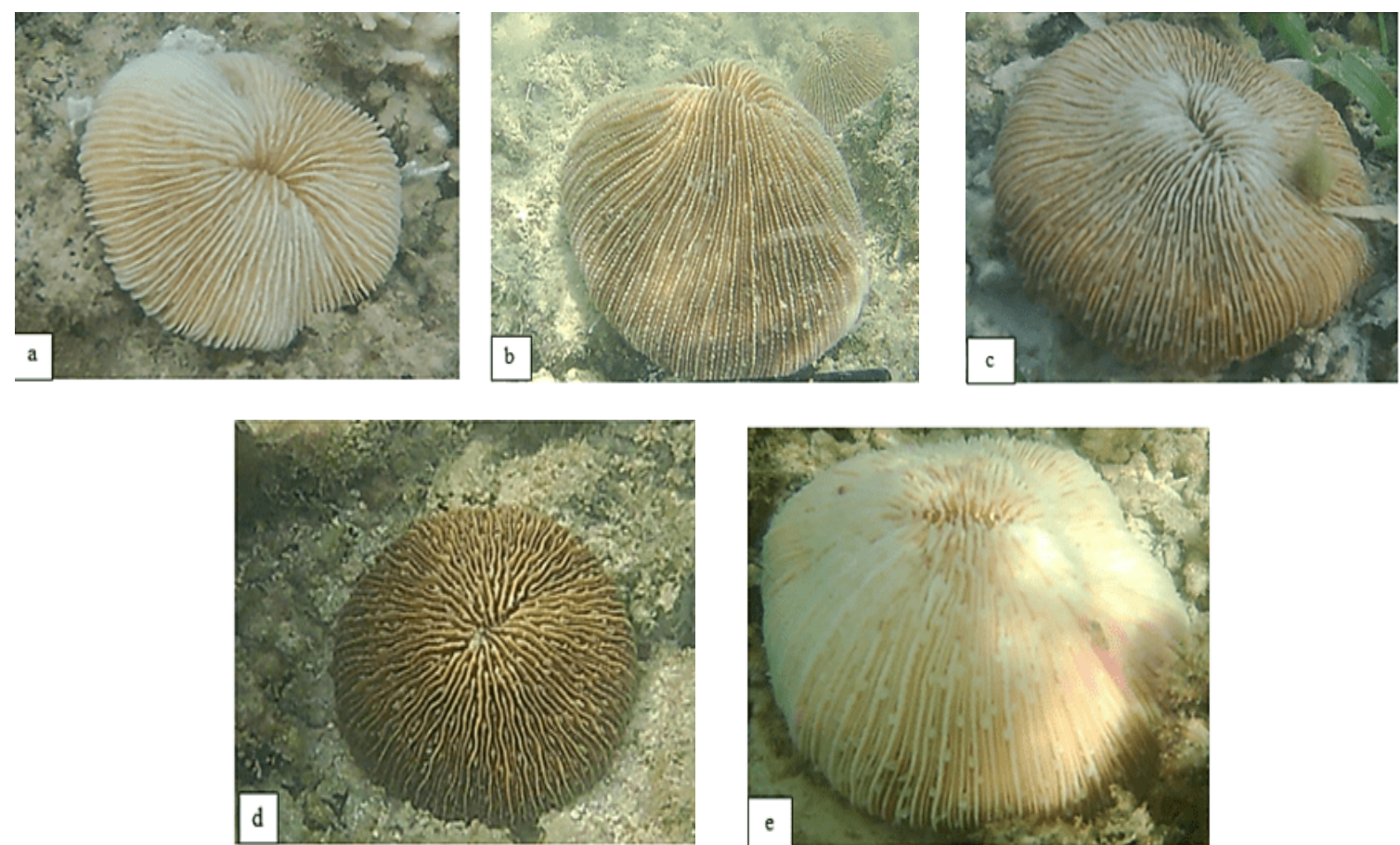

Gambar 2. Spesies Cycloseris vaughani (a), Fungia fungites (b), Fungia horrida (c), Fungia scabra (d), Fungia spinifer (e)

Tabel 1. Jumlah Individu dan komposisi Spesies Karang Jamur Perairan Pulau Kabung

\begin{tabular}{lcccc}
\hline \multirow{2}{*}{ Spesies } & \multicolumn{3}{c}{ Stasiun } & \multirow{2}{*}{ Total } \\
\cline { 2 - 4 } & I & II & III & \\
\hline Cycloseris vaughani & 26 & 38 & 19 & $\mathbf{8 3}$ \\
Fungia fungites & 27 & 33 & 11 & $\mathbf{7 1}$ \\
Fungia horrida & 9 & 9 & 24 & $\mathbf{4 2}$ \\
Fungia scabra & 29 & 21 & 11 & $\mathbf{6 1}$ \\
Fungia spinifer & 0 & 17 & 8 & $\mathbf{2 5}$ \\
\hline Total & $\mathbf{9 1}$ & $\mathbf{1 1 8}$ & $\mathbf{7 3}$ & $\mathbf{2 8 2}$ \\
\hline
\end{tabular}

\subsection{Pola Sebaran Karang Jamur di Perairan Pulau Kabung}

Pola sebaran karang jamur di Pulau Kabung ditemukan mengelompok dan acak disajikan pada (Tabel 2). Penyebaran spesies karang jamur yang ada di perairan Pulau Kabung cenderung mengelompok, atau memiliki nilai Indeks Morisita lebih besar dari 1 (IM>1), ditemukan pada spesies $C$. vaughani, $F$. horida, $F$. spinifer, $F$. fungites dan $F$. scabra pada masing-masing stasiun. Karang jamur yang memiliki pola sebaran acak (IM=1), ditemukan pada spesies $F$. scabra dari Stasiun I dan III. 
Jurnal Laut Khatulistiwa, Vol. 4. No. 3 (October, 2021), Hal. 101-108.

Tabel 2. Pola Sebaran Karang Jamur di Perairan Pulau Kabung

\begin{tabular}{lccccc}
\hline \multirow{2}{*}{ Stasiun } & \multicolumn{5}{c}{ Nilai Indeks Morisita (IM) } \\
\cline { 2 - 6 } & C. vaughani & F. fungites & F. horrida & F.scabra & F.spinifer \\
\hline I & 1,2 & 1,3 & 3,0 & 1,0 & - \\
II & 1,2 & 1,6 & 1,8 & 1,2 & 1,2 \\
III & 1,4 & 3,0 & 1,3 & 1,0 & 1,6 \\
\hline
\end{tabular}

3.3 Sebaran Faktor Lingkungan Di Perairan Pulau Kabung

Faktor lingkungan memiliki keterkaitan terhadap keberadaan spesies karang jamur yang dipengaruhi oleh kondisi habitat. Hasil pengukuran faktor lingkungan pada habitat karang jamur di perairan Pulau Kabung meliputi suhu, kedalaman, kecerahan, $\mathrm{pH}$, DO, $\mathrm{CO}_{2}$, salinitas, alkalinitas dan kalsium (Gambar 2).

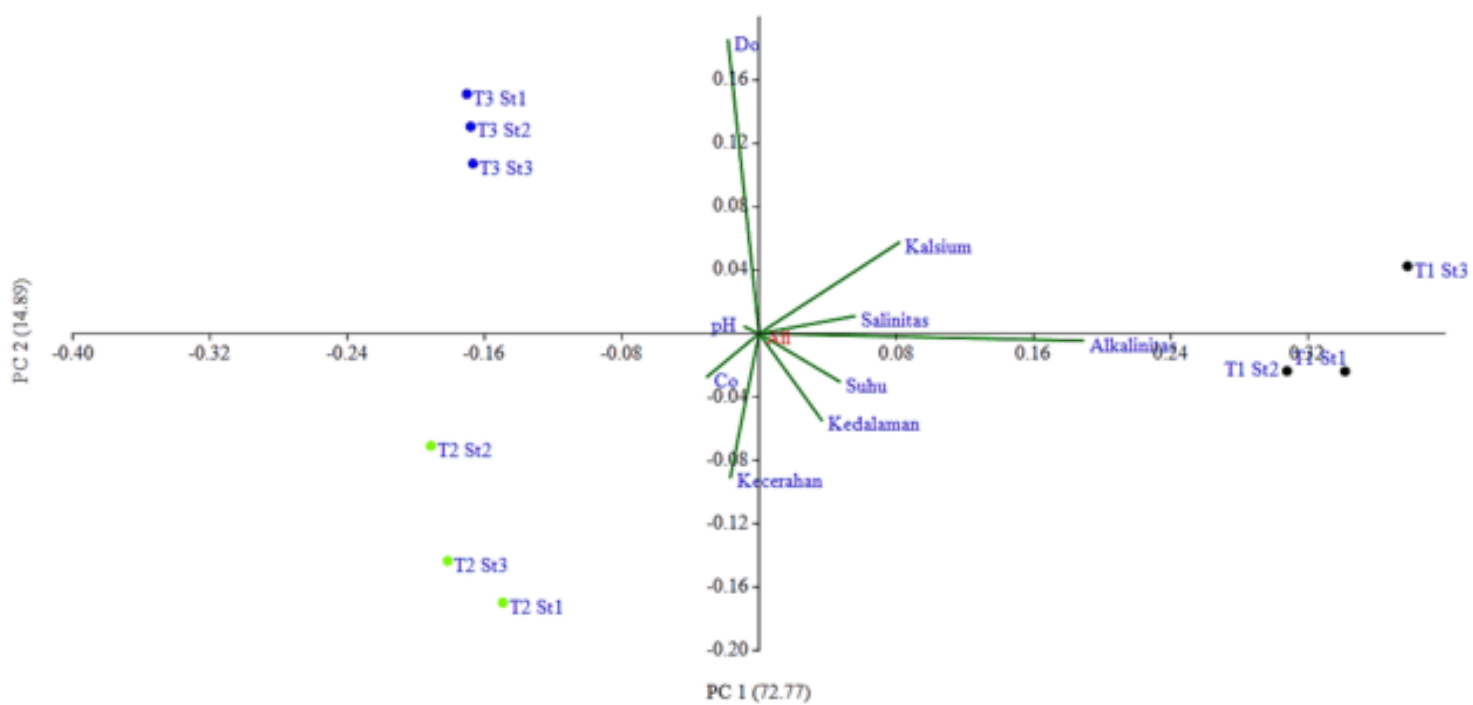

Keterangan $: \mathrm{T}=$ Stasiun, $\mathrm{St}=$ Stasiun transek

Gambar 2. Scatter Plot PCA Fisika Kimia Antar Stasiun di Pulau Kabung

Hasil analisis komponen utama yang ada pada Gambar 4.3 memperlihatkan bahwa pengelompokan faktor lingkungan pada perairan Pulau Kabung dari masing-masing

\section{Pembahasan}

Berdasarkan hasil penelitian yang dilakukan, diperoleh Karang Jamur (Fungiidae) yang ditemukan di perairan Pulau Kabung berjumlah lima spesies, terdiri atas empat genus Fungia berupa Fungia fungites (Gambar 1b), Fungia horrida (Gambar 1c), Fungia scabra (Gambar 1d) dan Fungia spinifer (Gambar 1e ) serta satu genus Cycloseris berupa Cycloseris vaughani (Gambar 1a) Komposisi spesies karang jamur yang stasiun, dapat menggunakan sumbu utama 1 dan 2. Kedua faktor ini sudah dapat menjelaskan nilai keragaman data dengan total nilai sebesar $87,67 \%$.

ditemukan disajikan pada Tabel 1. Jumlah spesies yang ditemukan di perairan Pulau Kabung pada penelitian ini relatif sedikit dibandingkan dengan penelitian Hermanto (2013), di perairan Pulau Siladen, Minahasa Utara, Sulawesi Utara yang menemukan 13 Spesies karang Fungiidae dari 7 genus. Hasil penelitian dari Souhoka (2016), di perairan Pulau Haruku, Kabupaten Maluku Tengah yang menemukan 12 spesies Fungiidae yang termasuk dalam 6 genus dengan spesies 
terbanyak dijumpai pada spesies Fungia sebanyak 6 spesies, Herpolitha sebanyak 2 spesies dan jenis lainnya masing-masing 1 spesies. Umumnya spesies karang Fungiidae yang ditemukan di perairan Pulau Kabung merupakan spesies-spesies yang umum dijumpai di perairan Indonesia (Suharsono, 2010).

Hasil penelitian di perairan Pulau Kabung menunjukkan kepadatan spesies karang jamur di setiap stasiun berbeda-beda. Pengaruh bentuk topografi yang curam yang terdapat pada Stasiun III, jika dibandingkan dengan stasiun lainnya diduga berpengaruh terhadap sedikitnya jumlah individu yang didapatkan, kemungkinan sebagian besar karang jamur yang baru melepaskan diri dari substrat pada fase pertumbuhan, jatuh ke lereng curam (Drop off) sehingga kehadiran dari karang jamur tersebut menjadi berkurang. Hoeksema (1989), menyatakan bahwa kondisi yang curam (Drop off) kurang cocok untuk pertumbuhan karang jamur, hal ini disebabkan kurangnya penetrasi cahaya yang masuk ke dalam perairan laut. Secara langsung juga berpengaruh terhadap proses fotosintesis oleh karang jamur sehingga dapat menghambat pertumbuhan karang jamur yang termasuk dalam tipe karang hermatifik. Karang hermatifik menurut Veron (1986), mampu tumbuh lebih cepat 2-3 kali, jika berada pada tempat yang terang.

Frekuensi kehadiran dari spesies karang jamur dengan nilai tertinggi dari tiga stasiun yang diteliti terdapat pada spesies karang $C$. vaugani, F.fungites, F. horida dan F. scabra dengan nilai frekuensi kehadiran 100\% dan nilai dengan frekuensi kehadiran terendah terdapat pada spesies F.spinifer dengan nilai 66,67\%. Menurut Hoeksema (2012), frekuensi individu tertinggi dari spesies karang Fungiidae yang dominan dapat berkontribusi dalam karakteristik pembentukan terumbu karang yang terjadi baik dalam substrat keras maupun lunak. Penelitian di perairan Pulau Kabung pada masing-masing stasiun penelitian memperlihatkan karakteristik habitat yang hampir sama berupa substrat bebatuan, cangkang moluska, serta substrat lunak seperti pasir halus dan sedikit berlumpur.

Kondisi lingkungan perairan sangat berpengaruh terhadap pola sebaran karang jamur yang ada di dalam suatu perairan. Hasil dari indeks Morisita dari tiga stasiun yang diamati, spesies karang jamur yang didapatkan cenderung mengelompok baik dari spesies $C$. vaugani, F. fungites, F.spinifer, dan F. horida memiliki nilai dari (IM>1), pada stasiun I dan III, spesies $F$. scabra memiliki pola sebaran acak (IM=1) (Tabel 2). Menurut Michael (1984), pola persebaran bergantung pada sifat fisika kimia lingkungan maupun keistimewaan biologis dari organisme itu sendiri. Karang jamur dapat bergerak dari satu tempat ke tempat lainnya (Gittenberg et al., 2011). Hal ini dapat menjadi faktor terjadinya perbedaan pola sebaran karang jamur, walaupun dalam penelitian Hoeksema dan Bongaerts (2016), mengungkapkan bahwa pergerakan pada karang jamur membutuhkan cukup banyak waktu dan cukup sulit diamati.

Dominannya pola sebaran mengelompok dari spesies karang Fungiidae, disebabkan terjadinya penyebaran secara bersamaan, dimana setiap masing-masing individu selalu ada dalam kelompok dan sangat jarang sekali terpisah (Michael, 1984). Hasil penelitian yang sama dari Souhoka (2016), di perairan Pulau Haruku, Kabupaten Maluku Tengah dari lima spesies karang jamur dominan yang ditemukan memiliki pola sebaran mengelompok, pola penyebaran mengelompok diduga karena adanya keragaman (heterogenity) habitat dan makanan sehingga terjadi pengelompokan di tempat yang terdapat banyak makanan (Tarumingkeng, 1994). Penelitian yang berbeda dari Nugraha (2004), pada perairan Kepulauan Karimunjawa pada spesies Fungia fungites memiliki sebaran merata yang disebabkan adanya persaingan keras dalam mendapatkan ruang dengan karang atau organismen lainnya. Sebaran ini terjadi untuk menghindari kontak dengan pesaing (Chadwick dan Loya, 1992).

Spesies karang Fungia scabra memiliki pola sebaran yang acak (random), menurut Odum (1992), menjelaskan pola sebaran acak ini relatif jarang terjadi di alam, pola sebaran acak ini terjadi dikarenakan terdapat kondisi suatu habitat yang hampir seragam. Pola sebaran ini menunjukkan bahwa perpindahan tempat atau mobilitas dari karang jamur juga dapat memengaruhi perbedaan pola persebaran karang jamur tersebut. Menurut 
Chadwick (1998), mobilitas merupakan starategi alternatif dalam sejarah kehidupan, pada karang sendiri dapat memberikan dampak yang unik bagi struktur komunitas terumbu karang, spesies karang yang hidup bebas (free living) seperti karang jamur dapat menjauhi untuk berinteraksi langsung secara kompetitif dengan terumbu karang yang berkoloni.

Menurut Keen (1987), larva pelagik invertebrata mampu membedakan antara habitat yang sesuai dan tidak sesuai bagi perkembangannya, larva mampu menunda metamorfosa apabila larva tersebut menemukan keadaan bahaya atau tempat yang tidak sesuai. Krupp (1983), setelah priode planktonik, yang terjadi selama dua minggu. Menurut Abe (1937), larva planula akan mencari substrat keras yang cocok untuk menetap. Goffredo dan Furman (2000), menyatakan beberapa karang jamur masih bisa ditemukan pada lokasi yang memiliki substrat berpasir, akan tetapi kehadirannya sangatlah rendah. Hal ini dipengaruhi oleh siklus hidup karang jamur yang membutuhkan substrat keras untuk menempel pada masa juvenil. Pada saat dewasa, spesies ini akan melepaskan diri dari substrat tersebut. Hoeksema dan Benzoni (2013), menyatakan bahwa ketika juvenil, karang jamur akan melekat pada substrat keras menggunakan tangkai batang karang atau stalk. Karang jamur yang baru saja terlepas dari substrat keras, akan memiliki bekas patahan pada bagian bawah polip (Vizel et al., 2009).

Analisis faktorial koresponden (Coresponden Analyisis) memeberikan informasi mengenai korelasi parameter lingkungan dengan individu karang jamur di perairan Pulau Kabung yang terpusat pada sumbu (PC) 1 dan 2 yang memiliki nilai ragam pada PC1 $(38,769 \%)$ dan PC2 $(30,675 \%)$ dengan total sebesar $(69,444 \%)$ (Gambar 2). Kuadran 1 memiliki nilai positif terhadap karang jamur spesies Fungia scabra (Fs) yang mencirikan kedalaman dan kecerahan. Menurut Nyabakken (1992), kecerahan adalah faktor penting yang memengaruhi kelimpahan dan pertumbuhan karang. Sukarno et al., (1981), menjelaskan kondisi perairan yang jernih mempunyai salinitas yang berkisar antara 30-31 ppt dan suhu air laut yang berkisar antara $28,50-29^{\circ} \mathrm{C}$ sangat mendukung untuk keberagaman karang jamur. Suharsono (2010), menyatakan karang jamur jenis Fungia scabra biasanya hidup pada daerah yang tenang serta bersubstrat dasar pasir. Ada beberapa faktor fisika dan kimia yang membatasi distribusi dan pertumbuhan karang antara lain faktor kecerahan, suhu dengan nilai $31-35^{\circ} \mathrm{C}$, salinitas $32-35 \mathrm{ppt}$, sedimentasi, dan arus (Nyabakken, 1992). Menurut Hoeksema (2013), kondisi habitat dan ekologis pada suatu lokasi merupakan salah satu faktor yang mempengaruhi keanekaragaman serta kepadatan karang jamur. Hasil penelitian Suharsono dan Yosephine (1994), menyatakan terdapat korelasi positif antara kedalaman maksimum karang hidup dengan kecerahan air. Pada perairan yang jernih memungkinkan penetrasi cahaya bisa sampai pada lapisan yang sangat dalam, sehingga karang juga dapat hidup pada perairan yang cukup dalam.

\section{Kesimpulan}

Distribusi horizontal karang jamur di perairan Pulau Kabung memiliki dua pola sebaran, yaitu mengelompok (C. vaughani, $F$. fungites, $F$. horida dan $F$. spinifer) dan acak ( $F$. scabra). Faktor lingkungan yang mempengaruhi distribusi karang jamur di perairan Pulau Kabung seperti kecerahan, oksigen terlarut, kalsium, dan alkalinitas.

Saran yang dapat diberikan pada penelitian tentang distribusi horizontal karang jamur di perairan Pulau Kabung yaitu perlu penelitian lebih lanjut untuk mengetahui persebaran karang jamur secara keseluruhan dengan cara distribusi vertikal dan tutupan terumbu karang di perairan Pulau Kabung maupun pulau-pulau kecil di perairan sekitar Kabupaten Bengkayang.

\section{Daftar Pustaka}

Abe, N. 1937. Post-larval Development of The Coral Fungia actiniformis varietas. Palau Tropical Biological Station Studies. (1):7393.

Chadwick, N.E. 1988. Competition and Locomotion in a Free-living Fungiid Coral. Journal of Experimental Marine Biology and Ecology. (123):189-200

Chadwick, N.F and Y, Loya. 1992. Migration, habitatuse and competition among mobil corals (Scleractinia: Fungiidae) in the gulf 
Jurnal Laut Khatulistiwa, Vol. 4. No. 3 (October, 2021), Hal. 101-108.

of eilat, red sea. Marine Biology. (114):617-623.

Dinas Kelautan dan Perikanan Provinsi Kalimantan Barat. 2005. Master Plan Kawasan Konservasi Laut Daerah Kabupaten Bengkayang. Pontianak: DKP Kalbar

English, S., Wilkinson., C and Baker., V. 1997. Survey Manual for Tropical Marine Resources 2nd ed. Australia: Australian Institute of Marine Science Townsville.

Goffredo S., Chadwick and Furman, 2003. Comparative Demography of Mushroom Corals (Scleractinia:Fungiidae) at Eilat. Marine Biology. (142):411-418.

Hermanto, B. 2013. Keanekaragaman Karang Jamur (Fungiidae) di Perairan Pulau Siladen. Jurnal Ilmiah Platax. 1(4):158166

Hoeksema, B.W. 1989. Taxonomy, Phylogeny and Biogeography of Mushroom Corals (Scleractinia Fungiidae). Zoologische Verhandelingen. (254):1-295.

Hoeksema, B.W. 2012. Distribution Patterns of Mushroom Corals (Scleractinia: Fungiidae) Across the Spermonde Shelf. The Raffles Bulletin of Zoology. (1):183212.

Hoeksema, B.W \& Benzoni. 2013. Multispecies Aggregation of Mushroom Corals in The Gambier Island. Coral reefs. (32):10-41.

Hoeksema, B.W., Obura, D.O., Wood, E., Rogers, A \& Quibilan, MC. 2014. Fungia fungites, The IUCN Red List of Threatened Species.

Keen, S,L. 1987. Recruitment of Aurelia aurita (Cnidaria:Scyphozoa) Larvae is Positiondependent, and Independent of Conspecific Density, Within a Settling Surface. Marine Ecology Progress Series. (35):151-160.

Krupp, F. 1983. Fishes of Saudi Arabia, Freshwater Fishes of Saudi Arabia and Adjacent Regions of The Arabian Peninsula. Fauna of Saudi Arabia. (5):568604.

Micheal, P. 1948. Metode Ekologi Untuk Penyelidikan dan Laboratorium. Jakarta: Universitas Indonesia Press.

Mampuk, F.H., Tioho dan J.D. Tusen. 2013. Distribusi Vertikal Dan Kepadatan Karang Fungiidae Di Perairan Malalayan. Jurnal Pesisir dan Laut. 1(1):41 - 44.
Nugraha, W.A. 2004. Distribusi dan Struktur Populasi Karang Soliter Fungia Fungites di Pulau Burung, Pulau Cemara, Kecil dan Pulau Menjangkan Kecil (Kepulauan Karimunjawa). Ilmu Kelautan. 3(9):174179.

Nyabkken, J.W. 1992. Biologi Laut, Suatu Pendekatan Ekologi. Jakarta: Gramedia.

Odum, H.T. 1992. Ekologi Sistem Suatu Pengantar. Yogyakarta: Gadjah Mada University Press.

Souhoka J. 2016. Struktur Komunitas Karang Jamur (Fungiidae) di Perairan Pulau Haruku. Biota. 2(1):51-61

Subhan, B., Rahmawati, F., Arafat, D dan N.A. Bayu. 2011. Kondisi kesehatan karang Fungiidae di perairan Pulau Pramuka. Jurnal Teknologi Perikanan dan kelautan. 2 (1):41-50.

Suharsono and Yosephine 1994. Perbandingan Kondisi Terumbu Karang di Pulau Nyamuk Besar dan Pulau Onrust Tahun 1929, 1985 dan 1993 dengan Hubungannya dengan Perubahan Peraiaran di Teluk Jakarta. Prosiding Seminar Pemantauan Pencemaran Laut, Jakarta, Indonesia. 7 September 1994.

Suharsono, 2010. Jenis-Jenis Karang Di Indonesia. Jakarta: Lembaga Ilmu Pengetahuan Indonesia COREMAP Program.

Tarumingkeng, R.C. 1994. Dinamika Populasi : Kajian Ekologi Kuantitatif. Jakarta: Pustaka Sinar Harapan dan Universitas Kristen Krida Wacana.

Veron, JEN. 1986. Corals of Australia and The Indo-Pacific. Australia: Angus and Robertson Publisher

Vizel, M.E., Winter., K \& Loya. 2009. Mushroom Coral Regeneration from a Detach Stalk. Coral Reefs. 939(28): 9-29.

Wilkinson, C. 2004. Status of coral reefs of the world. Australian Institute of Marine Science. Australia: Australian Institute of Marine Science.

Yamashiro, H. and K, Yamazato. 1996. Morphological studies of the soft tissues involved in skeletal dissolution in the coral Fungia fungites. Coral Reefs. (15):177-180. 